\title{
Nos tuis supplicationibus inclinati: Pope Innocent IV and the Decline of Delegated Jurisdiction in Hungary in the Mid- $13^{\text {th }}$ Century ${ }^{* *}$
}

\begin{abstract}
The paper discusses a special aspect of the papal-Hungarian relations, namely the operation of delegated jurisdiction after the Mongol invasion of 1241-42. The focus of the study is on the revival of the system in the 1240s, and on certain measures of Pope Innocent IV in 1252 and 1254. The first measure of this kind is traditionally considered to be the papal allowance granted to King Béla IV in order to avoid his ecclesiastical and lay subjects being cited outside of the realm. This prohibition, according to the opinion of the Hungarian legal historian György Bónis, was annulled as early as 1259. In the present study, we argue that, although the charters of Innocent IV and Alexander IV are indeed of great importance, their impact should not be overrated. The number of known cases supervised by the papal judges dropped significantly in the 1250s. However, the reason behind this decrease cannot be solely explained by the above-mentioned papal charter; other factors should also be considered in investigating this question.
\end{abstract}

Keywords: Pope Innocent IV, $13^{\text {th }}$ century, relations, King Béla IV

The paper discusses a special aspect of the papal-Hungarian relations, namely the operation of delegated jurisdiction after the Mongol invasion of 1241-42. The devastation caused by the Mongol army - together with the sedis vacantia ${ }^{1}$ between November 1241 and June 1243 following the death of Celestine IV - and the election of Innocent IV (1243 - 1254) marked a clear caesura in the operation of the delegated jurisdiction system in the Hungarian Church. It is therefore worth examining whether a change can be detected in comparison with the former decades, ${ }^{2}$ and also how the relationship be-

\footnotetext{
* Gábor Barabás, Department of Medieval and Early Modern History, University of Pécs, Rókus u. 2, H-7624 Pécs, Hungary, E-mail: barabas.gabor@pte.hu, barab.gabor@gmail.com

** Research for this article was supported by the János Bolyai Research Scholarship of the Hungarian Academy of Sciences (BO/00148/17/2). I am grateful to Fanni Madarász, Prof. Endre Sashalmi, and Alexandra Hatter for the correction of the text. This is the English version of the article published in Hungarian language in Aetas vol. 35 (2020), No. 2: 126-141.

1 Klaus Herbers, Geschichte des Papsttums im Mittelalter (Darmstadt: WBG, 2012), 185.

2 For the situation in Hungary, see with further literature: Gábor Barabás, "A pápai kiküldött bíráskodás Magyarországon a kezdetektől a 13. század közepéig” [Delegated papal jurisdiction in Hungary from its origins to the mid-13th century], Történelmi Szemle 55 (2013): 183-199; Gábor Barabás, Das Papsttum und Ungarn in der ersten Hälfte des 13. Jahrhunderts (ca. 1198 - ca. 1241). Päpstliche
} 
tween King Béla IV (1235-1270) and Pope Innocent IV affected this system. Especially so because a charter of Pope Innocent IV from 1252 is traditionally considered to be a papal allowance granted to King Béla IV in order to avoid his ecclesiastical and lay subjects being cited outside of the realm. This prohibition, according to the opinion of the Hungarian legal historian György Bónis, was annulled as early as 1259 by the successor of Innocent IV. According to our hypothesis, the charters of Innocent IV and Alexander IV (1254-1261) are indeed of great importance; nevertheless, the nature of their impact on the operation of papal delegated jurisdiction should be carefully reconsidered.

In order to be able to implement a comparative approach, first we have to take a closer look at the characteristics of papal delegated jurisdiction and its way of functioning in the Árpádian-era Hungary. Delegated jurisdiction was one of the most important instruments of the papacy from the late 11th century onwards. ${ }^{3}$ The foundation of the system was rooted in the willingness of churches and clerics to turn to the Apostolic See for a judicial decision, with the aim of having the verdict validated by the papal authority. The system itself can be linked to the reform of the papacy at the outset of the 11th century (and to its power over the Church and its universal claims). ${ }^{4}$

Papal delegated jurisdiction gave an opportunity to the local churches to evade the level of ordinary courts as well. ${ }^{5}$ At the same time, it is interesting to note that the delegate judges came from the circle of local clerics, who, at first, were mostly archbishops, bishops and abbots. Thus, we can conclude that the needs of the parties affected the development of the judiciary system itself. ${ }^{6}$ It was in the very best interest

Einflussnahme - Zusammenwirken - Interessengegensätze (Vienna: Institut für Ungarische Geschichtsforschung in Wien; Balassi Institut - Collegium Hungaricum Wien; Ungarische Archivdelegation beim Haus-, Hof- und Staatsarchiv, 2014), 72-87. For the historiography, see Gábor Barabás, “A középkori pápai delegáltbíróság nemzetközi és magyar kutatástörténete [A history of international and Hungarian research on medieval papal delegated jurisdiction], Egyháztörténeti Szemle 20 (2019): 3-23.

3 James Ross Sweeney, “Innocent III, Canon Law and Papal Judges Delegate in Hungary,” in: Popes, Teachers, and Canon Law in the Middle Ages, ed. James Ross Sweeney and Stanley Chodorow (Ithaca; New York: Cornell University Press, 1989), 26.

4 Barabás, “A pápai kiküldött”, 175.

5 Barabás, “A pápai kiküldött”, 175-176, with further literature.

$6 \quad$ See John S. Ott, "Men on the Move: Papal Judges-Delegate in the Province of Reims in the Early Twelfth Century", in: The Use of Canon Law in Ecclesiastical Administration, 1000-1234, ed. Melodie Eichbauer and Danica Summerlin (Leiden; Boston: Brill, 2019), 24-26; Matthias Schrör, Metropolitangewalt und papstgeschichtliche Wende (Husum: Matthiesen Verlag, 2009), 129-137; Othmar Hageneder, Die geistliche Gerichtsbarkeit in Ober- und Niederösterreich. Von den Anfängen bis zum Beginn des 15. Jahrhunderts (Linz: Hermann Böhlaus Nachf., 1967), 27; Peter Herde, "Zur päpstlichen Delegationsgerichtsbarkeit im Mittelalter und in der frühen Neuzeit”, Zeitschrift der Savigny-Stiftung für Rechtsgeschichte. Kanonische Abteilung 119 (2002): 22; Ludwig Falkenstein, "Appellationen an den Papst und Delegationsgerichtsbarkeit am Beispiel Alexanders III. und Heinrichs von Frankreich", Zeitschrift der Kirchengeschichte 97 (1986): 37-39; Jochen Johrendt and Harald Müller, "Zentrum und Peripherie. Prozesse des Austausches, der Durchdringung und der Zentralisierung der lateinischen Kirche im Hochmittelalter", in: Römisches Zentrum und kirchliche Peripherie. Das universale Papsttum als Bezugspunkt der Kirchen von den Reformpäpsten bis zu Innozenz III., ed. Jochen Johrendt and Harald Müller (Berlin; New York: De Gruyter, 2008), 14; Charles Duggan, "Papal Judges Delegate and the Making of the 'New 
of the papacy that the local clerics and churches should turn to the pope as the Holy See intended to increase its authority. ${ }^{7}$

The expansion of the system may be attributed to Pope Alexander III (1159 - 1181), and the development of the judicial background ended by the time of the Fourth Lateran Council. The increasing number and growing geographical scope of the delegations have been contributed to the spreading of canon law in the regions of Western Christendom. ${ }^{8}$ The system of delegations was a significant instrument of the papacy, which helped the popes shape Western Christianity and influence its regions. The original initiative came from them, as they had a word on the selection of the judges. ${ }^{9}$

Besides the judges, another group of papal delegates has to be mentioned: the executors (executores), whose authorization represented a lower level. ${ }^{10}$ Unlike the iudices delegati, they did not pass a sentence, their tasks were limited to the execution of former decisions or to the examination of certain petitions, and they were also expected to engage in ecclesiastical censures in certain cases. It was not forbidden though for one and the same person to fill both positions. ${ }^{11}$ Besides the iudices delegati, the office of conservators needs to be mentioned as well: it was a position with general authorization but limited jurisdiction. Its main purpose was to preserve the rights or possessions of certain individuals or churches, and even entire orders could have

Law' in the Twelfth Century", in: idem, Decretals and the Creation of "New Law" in the Twelfth Century: Judges, Judgements, Equity, and Law (Aldershot; Brookfield; Singapore; Sydney: Ashgate, 1998), 176 and 194-195.

7 Harald Müller, "Entscheidung auf Nachfrage. Die delegierten Richter als Verbindungsglieder zwischen Kurie und Region sowie als Gradmesser päpstlicher Autorität", in: Römisches Zentrum und kirchliche Peripherie Das universale Papsttum als Bezugspunkt der Kirchen von den Reformpäpsten bis zu Innozenz III., ed. Jochen Johrendt and Harald Müller (Berlin; New York: De Gruyter, 2008), 109-110; Johrendt and Müller, "Zentrum und Peripherie", 14; Duggan, "Papal Judges Delegate", 176-177.

8 Lotte Kéry, "Dekretalenrecht zwischen Zentrale und Peripherie", in: Römisches Zentrum und kirchliche Peripherie. Das universale Papsttum als Bezugspunkt der Kirchen von den Reformpäpsten bis zu Innozenz III., ed. Jochen Johrendt and Harald Müller (Berlin; New York: De Gruyter, 2008), 19-45.

9 Barabás, "A pápai kiküldött”, 177-178, with further literature.

10 George G. Pavloff, Papal Judge Delegates at the Time of the Corpus Iuris Canonici (Washington, DC: The Catholic University of America Press, 1963), 23; Hageneder, Die geistliche Gerichtsbarkeit, 48; Falkenstein, "Appellationen", 41-42; Jane E. Sayers, Papal Judges Delegate in the Province of Canterbury 1198-1254: A Study in Ecclesiastical Jurisdiction and Administration (Oxford: Oxford University Press, 1971), 17-18. Cf. Andreas Holndonner, Kommunikation - Jurisdiktion - Integration Das Papsttum und das Erzbistum Toledo im 12. Jahrhundert (ca. 1085 - ca. 1185) (Berlin; Munich; Boston: De Gruyter, 2014), 16.

11 Cf. Harald Müller, Päpstliche Delegationsgerichtsbarkeit in der Normandie (12. und frühes 13. Jahrhundert) (Bonn: Bouvier Verlag, 1997), 62-63; Frank Engel, "Die Diözese Ávila und die päpstliche Delegationsgerichtsbarkeit im 12. Jahrhundert", in: Das begrenzte Papsttum. Spielräume päpstlichen Handelns Legaten - delegierte Richter - Grenzen, ed. Klaus Herbers, Fernando López Alsina and Frank Engel (Berlin; Boston: De Gruyter, 2013), 297; Thomas W. Smith, "Papal Executors and the Veracity of Petitions from Thirteenth-Century England", Revue d'Histoire Ecclésiastique 110 (2015): 664ff; Sayers, Papal Judges Delegate, 155-162. 
a protector of this kind. Conservators could be appointed even after the sentences of the judges' delegate. ${ }^{12}$

The first data regarding the operation of the delegations in the Hungarian realm come from the 12th century, but the wide and relatively fast spreading of the system is a unique feature of the early 13 th century. This statement is based on the number of known cases and the circle of the selected judges. The situation in Hungary shows similarities to the tendencies of Western regions, although the sources outline the differences as well, most notably with regard to certain categories of cases (usury, overpricing, etc.). Nonetheless, the foundation of the system and its practical operation, the main categories of the cases, and the details of the procedures followed the general pattern, if a pattern existed at all. Among other things, the increasing role of the middle clergy in delegated jurisdictions is traceable. Not only the quality, but also the quantity of this improvement is impressive: after the first sporadic data, application of the papal judiciary system and the delegations in Hungary became a general phenomenon in the first half of the 13th century. ${ }^{13}$

$* * *$

The events of 1241-42, the Mongol invasion and the almost parallel sedis vacantia of the papacy marked a clear caesura in terms of delegated jurisdictions as well. This paper will examine, with the help of the known cases, how the system re-emerged in the realm of Saint Stephen, how the abovementioned measure of Innocent IV affected it, and what kind of new tendencies and phenomena can be traced, if any at all, in the period the end of which is marked by the death of Pope Innocent IV in 1254.

In 1243, the destructions of the Mongol invasion still determined the situation, among other things the papal delegated jurisdiction. ${ }^{14}$ A relevant part of the Hungarian higher clergy had fallen prey to the invaders, including both archbishops. ${ }^{15}$ Therefore, it is not surprising that the first measures of Innocent IV dealt with this situation: filling

12 Sayers, Papal Judges Delegate, 108-109 and 265. Gábor Kiss, “A conservatores hivatala, mint a pápai küldöttbíráskodás sajátos megjelenése az érett középkorban” [The office of conservatores as a special occurrence of papal delegated jurisdiction in the High Middle Ages], Fons 22 (2015): 91-102; Gergely Kiss, “A pápai képviselet” [Papal representation], in: Varietas delectat A pápai-magyar kapcsolatok sokszínüsége a 11-14. században, ed. Gergely Kiss (Pécs: PTE BTK TTI, 2019), 48-49.

13 See Barabás, “A pápai kiküldött”, 183-199; Barabás, Das Papsttum, 72-88.

14 For the Mongol invasion and its affects, see recently: József Laszlovszky, Stephen Pow, Beatrix F. Romhányi, László Ferenczi, and Zsolt Pinke, "Contextualizing the Mongol Invasion of Hungary in 1241-42: Short- and Long-Term Perspectives”, Hungarian Historical Review 7 (2018): 419-450.

15 Thomae archidiaconi Spalatensis Historia Salonitanorum atque Spalatinorum pontificum. Archdeacon Thomas of Split, History of the Bishops of Salona and Split, ed. Olga Perić, Damir Karbić, Mirjana Matijević Sokol, and James Ross Sweeney (Budapest; New York: CEU Press, 2006), 268-269 and 272-273; Magistri Rogerii, Epistola in miserabile carmen super destruction regni Hungariae per Tartaros facta, translated and annoted by János M. Bak and Martin Rady (Budapest; New York: CEU Press, 2010), 186-189; Attila Zsoldos, Magyarország világi archontológiája 1000-1301 [Lay Archontology of Hungary, 1000-1301] (Budapest: MTA TTI, 2011), 81, 84, 89, 91, and 93; Jenő Szűcs, “A kereszténység belső politikuma a XIII. század derekán. IV. Béla és az egyház" [The inner policy of Christianity in the mid-13 century: King Béla IV and the Church], Történelmi Szemle 21 (1978): 167. 
in the positions of the archbishops of Esztergom and Kalocsa. ${ }^{16}$ The vacant bishopric of Györ and the archdeaconate of Sopron were also the subjects of the activity of papal delegates. ${ }^{17}$ The chronicler of the Mongol invasion, Roger of Apulia, ${ }^{18}$ the former archdeacon of Várad (Oradea, RO), received the latter position. ${ }^{19}$

Nonetheless, after the first delegations, those given for executors, judicial mandates in a narrow sense, were issued in late 1244 and early 1245 and concerned cases of "traditional nature", such as the litigation of the Benedictine Abbey of Pannonhalma with the cathedral chapter of Veszprém, ${ }^{20}$ or the Benedictines' quarrel with Demetrius of the Csák kindred, the former royal judge. ${ }^{21}$ The fact itself is important that the Apostolic See initiated new delegations already by the turn of 1244-45, yet - as various passages of the papal charters clearly indicate - the new mandates had to be issued because of the death of the former judges. ${ }^{22}$ Therefore, it can be stated that the papacy had to deal with the continuity of ongoing litigations and the renewal of the former structure. The issue was not about the new initiatives coming from the Realm of Saint Stephen, i.e., the need to implement the universal papacy and the delegated jurisdiction in a country just emerging from a catastrophe. It is also of crucial importance that, similarly to the previous decades, the abbey of Pannonhalma appeared on numerous occasions as one of the litigants, which can partly be explained by its

16 Regesta Pontificum Romanorum inde ab anno post Christum Natum MCXCVIII ad annum MCCCIV, ed. August Potthast (Berlin, 1874), No. 110181; Les registres d'Innocent IV. I-IV, ed. Élie Berger (Paris, 1881-1919), No. 11; Regesta Pontificum Romanorum, No. 11091; Les registres d'Innocent IV, No. 19; Regesta Pontificum Romanorum, No. 11413; Esztergomi érsekek. 1001-2003 [Archbishops of Esztergom, 1001-2003], ed. Margit Beke (Budapest: Szent István Társulat, 2003), 106-107; Gergely Kiss, Dél-Magyarországtól Itáliáig. Báncsa nembeli István (1205 k. - 1270) váci püspök, esztergomi érsek, az első magyarországi bíboros életpályája [From southern Hungary to Italy: The life path of Stephen Báncsa (ca. 1205-1270), Bishop of Vác, Archbishop of Esztergom, and the first cardinal of Hungarian origin] (Pécs: Kronosz, 2015), 23-25; József Udvardy, A kalocsai érsekek életrajza (1000-1526) [Biography of the archbishops of Kalocsa (1000-1526)] (Cologne: Görres Gesellschaft, 1991), 134-135; Szücs, "A kereszténység belső", 166-167.

17 Regesta Pontificum Romanorum, No. 11084; Les registres d'Innocent IV, No. 9; Regesta Pontificum Romanorum, No. 11173.

18 Magistri Rogerii, Epistola in miserabile carmen.

19 Tibor Almási, “Megjegyzések Rogerius magyarországi méltóságviseléséhez" [Remarks on the offices of Roger in Hungary], Acta Universitatis Szegediensis de Attila József nominate. Acta Historica 86 (1988): 9 and 11-13.

20 Regesta Pontificum Romanorum, No. 11482.

21 Regesta Pontificum Romanorum, No. 11487. See Zsoldos, Magyarország világi, 29 and 54; Richárd Horváth, “A favár rejtélye, avagy mennyire régi Újvár vára?: Németújvár várának 'vélelmezett' története a kezdetektől a 13. század végéig" [The mystery of the wooden castle, or: How old is the castle of Güssing? The presumed history of the castle of Güssing from its beginnings to the end of the 13th century], Castrum - A Castrum Bene Egyesület Hirlevele 18 (2015): 17-18.

22 ... quia dicti iudices fuerunt a Tartaris interfecti. Monumenta Romana Episcopatus Vesprimiensis - A veszprémi püspökség római oklevéltára. I-IV, ed. Vilmos Fraknói and József Lukcsics (Budapest, 1896-1907), I, 118, No. CXXXVII. Cf. Kiss, Dél-Magyarországtól Itáliáig, 27. 
extraordinary archive preserving its charters. ${ }^{23}$ However, it is also significant that the Benedictine monks did not overlook the corroboration of their rights by the Holy See. The question of another vacant bishopric led to a new delegation in 1245, yet this issue was not generated by the Mongol invasion. The canons of Veszprém elected one of their own, Zeland, after the death of Bishop Bartholomew ${ }^{24}$ in 1244, and the decision was confirmed by Archbishop Stephen of Esztergom. ${ }^{25}$ Nonetheless, Pope Innocent IV ordered Archbishop Benedict of Kalocsa - due to the complaint of King Béla IV, who did not give his blessings to the election - to examine the case. ${ }^{26}$ Ultimately, Zeland was able to keep the bishop's position ${ }^{27}$ despite the monarch's objection, even though he also appeared as a petitioner in the sources as early as 1245 - he had litigation with the abbeys of Pannonhalma and Bélakút (Petervaradin, SRB). ${ }^{28}$

The quarrel between the cantor of Veszprém and the abbey of Kapornak took place in 1245 as well, ${ }^{29}$ just like the controversy between the bishop and the archdeacons of Eger, and certain priests of the diocese. ${ }^{30}$ The first papal mandate given to a Hungarian clergyman as a conservator ${ }^{31}$ was also issued in 1245 ; however, the authorization given to the archbishops of Esztergom and Kalocsa alongside the bishop of Zagreb concerning the protection of the Franciscan order was not a Hungarian matter in a strict sense, but rather part of a general provision. ${ }^{32}$ In 1246, Pope Innocent IV addressed the issue of the bishopric of Bosnia, which had been an immediate subject of the Apostolic See since the activity of Cardinal-legate Jacob of Pecoraria in $1233,{ }^{33}$ and now the Holy Father transferred the task to his delegates to place the diocese under the jurisdiction and supervision of the archbishop of Kalocsa. ${ }^{34}$

23 See Gáspár Csóka, "Liber ruber”, in: Korai Magyar Történeti Lexikon, ed. Gyula Kristó, Pál Engel, and Ferenc Makk (Budapest: Akadémiai Kiadó, 1994), 409.

24 Zsoldos, Magyarország világi, 100.

25 See Kiss, Dél-Magyarországtól Itáliáig, 28-29; Szűcs, “A kereszténység belső”, 168.

26 Regesta Pontificum Romanorum, No. 11567; Les registres d'Innocent IV, No. 1074.

27 Zsoldos, Magyarország világi, 100.

28 Regesta Pontificum Romanorum, No. 11910; Monumenta Romana Episcopatus Vesprimiensis, I, 122, No. CXLIII.

29 Monumenta Romana Episcopatus Vesprimiensis, I, 121, No. CXLII; 122, No. CXLIII; 124, No. CXLVI.

30 Regesta Pontificum Romanorum, No. 11821.

31 Kiss, "A conservatores hivatala”, passim.

32 Regesta Pontificum Romanorum, No. 11812. Cf. Regesta Pontificum Romanorum, No. 11811; Les registres d'Innocent IV, No. 1481 and 1878; See Kiss, Dél-Magyarországtól Itáliáig, 28.

33 Tibor Almási, "Egy ciszterci bíboros a pápai világhatalom szolgálatában. Pecorari Jakab magyarországi legációja" [A Cistercian cardinal in the service of the papal worldpower: The Hungarian legation of Jacob of Pecorari], Magyar Egyháztörténeti Vázlatok 5 (1993): 133-141; Nedim Rabić, "Im toten Winkel der Geschichte: Johannes von Wildeshausen als Bischof von Bosnien 1233/34-1237", in: Die deutschen Dominikaner und Dominikanerinnen im Mittelalter, ed. Sabine Heusinger, Elias H. Füllenbach, Walter Senner, and Klaus-Bernward Springer (Berlin; Boston: De Gruyter, 2016), 56-58.

34 Regesta Pontificum Romanorum, No. 12233; Les registres d'Innocent IV, No. 2034; Regesta Pontificum Romanorum, No. 12664; Les registres d'Innocent IV, No. 3204. Stephen Báncsa was nominated papal legate regarding the case. Regesta Pontificum Romanorum, No. 12246 and 12247 (Les registres d'Innocent IV, No. 2050 and 2051). See Kiss, Dél-Magyarországtól Itáliáig, 31-32; Bálint Ternovácz, "A 
Based on these examples, it seems justified to state that after the destruction of 124142 and the partially parallel sedis vacantia, the start of the pontificate of Innocent IV in 1243 offered a chance of revival for the delegations in the Hungarian realm, which became nearly as active as they had been prior to the unfortunate events. Apart from the previously mentioned cases, the ongoing dispute in 1247 between the archbishop of Kalocsa and the bishop of Pécs over the borders of their dioceses further strengthens this statement: after settling this case, the papal delegates were entrusted to deal with the gravamen of Archbishop Benedict. ${ }^{35}$ In the following year, the bishop of Veszprém turned to the Holy See because of the confiscation of his diocese's incomes and possessions. ${ }^{36}$ Apart from the authorizations as judges and conservators, Innocent IV mandated Hungarian clerics as executors too. Just like in the previous year, 1247, when the Cistercian abbot of Pilis and the provost of Eger were commissioned to force the abbot and the convent of Pannonhalma to follow the papal order considering the rights of the archbishop of Esztergom. ${ }^{37}$

Without attempting to fully enumerate each and every relevant papal mandate, ${ }^{38}$ we have to turn our focus to the key document of the selected era, a charter of Innocent IV issued on December 3, 1252. It is one of the most important sources in terms of the operation and expansion of delegated jurisdiction in mid-13th century Hungary. The Pope informed King Béla IV in his letter ${ }^{39}$ that, as a result of the monarch's former request, he

boszniai latin püspökség története 1344-ig" [History of the Latin bishopric of Bosnia until 1344], in: Micae Mediaevales V. Fiatal történészek dolgozatai a középkori Magyarországról és Európáról, ed. Laura Fábián, Judit Gál, Péter Haraszti Szabó, and Dorottya Uhrin (Budapest: ELTE BTK Történettudományi Doktori Iskola, 2016), 221-223; Gábor Barabás, "Heretics, Pirates, and Legates: The Bosnian Heresy, the Hungarian Kingdom, and the Popes in the Early 13th Century", Specimina Nova Pars Prima Sectio Mediaevalis 9 (2017): 55-57.

35 Regesta Pontificum Romanorum, No. 12696; Les registres d'Innocent IV, No. 3262.

36 Monumenta Romana Episcopatus Vesprimiensis, I, 126, No. CL.

37 Regesta Pontificum Romanorum, No. 12641.

38 Regesta Pontificum Romanorum, No. 12691; Les registres d'Innocent IV, No. 3261; Regesta Pontifcum Romanorum, No. 13034; Les registres d'Innocent IV, No. 4171; Regesta Pontificum Romanorum, No. 14011; Magyar Nemzeti Levéltár Országos Levéltára, Diplomatikai Levéltár [National Archive of Hungary], 4815; Regesta Pontificum Romanorum, No. 14062; Regesta Pontificum Romanorum, No. 14418; Regesta Pontificum Romanorum, No. 144491; Les registres d'Innocent IV, No. 5799; Regesta Pontificum Romanorum, No. 14705; Regesta Pontificum Romanorum, No. 14769; Les registres d'Innocent IV, No. 6085; Monumenta Romana Episcopatus Vesprimiensis, I, 127, No. CLI.

39 For the relations between Pope Innocent IV and Béla IV, see Toru Senga, "IV. Béla külpolitikája és IV. Ince pápához intézett 'tatár-levele'," [The foreign policy of Béla IV and his so-called "Tatar letter" sent to Pope Innocent IV], Századok 121 (1987): 584-612; Szűcs, “A kereszténység belső”, 164-171. 
forbade clergymen and laymen from Hungary to be cited outside of the realm, ${ }^{40}$ at least not without a special permission of the Apostolic See. ${ }^{41}$

Nevertheless, it is not completely clear how Béla IV submitted his request: in the form of a charter or in a verbal statement of his envoys. ${ }^{42}$ The latter version seems more plausible, since the monarch kept on sending his emissaries to the Apostolic See from the beginning of the Mongol invasion ${ }^{43}$ and, as a matter of fact, he even had a permanent agent in the papal court, Bishop Bartholomew of Pécs. ${ }^{44}$ The later archbishop of Esztergom, at that time bishop of Vác, Stephen Báncsa, was the first in the line of royal envoys in $1241,{ }^{45}$ but his role in the papal-Hungarian relations was far more important than that. He received several papal commissions after 1243 as a judge delegate and legate, and in December 1251, he was promoted to the cardinals' college as the bishop of Preneste, thus becoming its first member of Hungarian origin. ${ }^{46}$

The relationship between Archbishop Stephen and the Hungarian monarch was not always peaceful in the 1240s, as the above-mentioned disagreement on the election of the bishop in Veszprém demonstrates, in which case Stephen Báncsa confirmed the election despite the lack of royal consent. ${ }^{47}$ In connection with this affair, one of the leading Hungarian medievalists in the second half of the 20th century, Jeno" Szücs, suggested that the motive behind the archbishop's decision could be his personal bias, since after the Mongol invasion, Stephen Báncsa - despite the emerging custom - did not receive the position of the royal chancellor. ${ }^{48}$ Instead, the title was

40 Benedict as the provost of Fehérvár received the privilege from Gregory IX in June 1241 stating that no one could sue him in the papal curia in the time of the Mongol invasion. Regesta Pontificum Romanorum, No. 11036; Les registres de Grégoire IX. Recueil des bulles de ce pape publiées et analysées d'après les manuscrits originaux du Vatican par Lucien Auvray, t. I-IV (Paris, 1890-1955), No. 6055. Cf. Gábor Thoroczkay, “A magyar Aachen első évszázada: a székesfehérvári prépostság története az Árpád-korban" [The first century of the Hungarian Aachen: History of the provostry of Székesfehérvár in the Árpádian era], in: Szent Márton és Benedek nyomában. Tanulmányok Koszta László emlékére, ed. Tamás Fedeles and Zsolt Hunyadi (Szeged and Debrecen: FIKP "Magyarország a középkori Európában” - Szegedi Tudományegyetem Középkori és Kora Újkori Magyar Történeti Tanszék, 2019), 535.

41 Nos tuis devotis supplicationibus inclinati, auctoritate presentium indulgemus, ut nulla ecclesiastica secularisque persona regni tui possit per litteras apostolice sedis, vel legatorum eius, extra regnum ipsum a quopiam in iudicium evocari, absque speciali mandato sedis eiusdem, faciente plenam de hac indulgentia mentionem... - Codex diplomaticus Hungariae ecclesiasticus ac civilis I-XI, ed. Georgius Fejér (Buda, 1829-1844), IV/2, 129; Regesta Pontificum Romanorum, No. 14795; Les registres d'Innocent IV, No. 6134.

42 See Regesta regum stirpis Arpadianae critico-diplomatica - Az Árpád-házi királyok okleveleinek kritikai jegyzéke, ed. Imre Szentpétery and Iván Borsa (Budapest, 1923-1943).

43 See Szücs, “A kereszténység belső”, 165. Cf. e.g. Regesta regum, No. 846.

44 László Koszta, “Egy francia származású föpap Magyarországon. Bertalan pécsi püspök (12191251)" [A French prelate in Hungary: Bishop Bartholomew of Pécs (1219-1251)], in: idem, Irásbeliség és egyházszervezet. Fejezetek a középkori magyar egyház történetéből (Szeged: Szegedi Egyetemi Kiadó, 2007) (Capitulum III.), 41; Iulian Mihai Damian, "Eneco ferences szerzetes inquisitiója Pécs püspökével szemben (1267)" [The inquisition of the Franciscan friar Enecus against the bishop of Pécs (1267)], Egyháztörténeti Szemle 17 (2016), No 2: 20-21. Cf. Regesta regum, No. 933b.

45 See Kiss, Dél-Magyarországtól Itáliáig, 22-23 and 30; Szűcs, “A kereszténység belső”, 165.

46 For his appointment as cardinal, see Kiss, Dél-Magyarországtól Itáliáig, 32-41.

47 See above and Szűcs, “A kereszténység belső”, 168; Kiss, Dél-Magyarországtól Itáliáig, 28-29.

48 Szűcs, “A kereszténység belső”, 168. 
granted to Archbishop Benedict of Kalocsa, the former provost of Obuda (later the elected provost of Fehérvár). ${ }^{49}$ Szücs admitted though that it was impossible to decide whether the conflict between Béla IV and Stephen Báncsa could be traced back to the monarch's decision; in his view, it is also questionable whether the confirmation of the archbishop in 1245 was related to that at all, or whether the quarrel around the election in Veszprém caused the tension in the first place. ${ }^{50}$ Nevertheless, it seems rather unrealistic that the king's decision regarding the royal chancellor could have been the origin of the conflict, since it was not the first time that the position was not filled by the respective archbishop of Esztergom, but by someone else, e.g. by the provost of Fehérvár. ${ }^{51}$ Furthermore, what seems to be more convincing is that Stephen Báncsa received the royal assignment to act as the king's emissary at the papal court right after the above-mentioned events, therefore we have no reason to suspect any differences between the monarch and the prelate in $1241 . .^{52}$

Be that as it may, it is obvious that Stephen Báncsa left the Kingdom of Hungary for Italy in the fall of 1252. Jenő Szücs has stated that the reason for this move was the increasingly inconvenient situation of Báncsa, due to his conflict with Béla IV. ${ }^{53}$ Meanwhile, apart from the promotion to the cardinalate, the favour of Pope Innocent IV was clearly expressed in the referenced mandates given to the archbishop. ${ }^{54}$ In our opinion, the "Veszprém election dispute" of 1245 is in itself not a sufficient proof to support the presumption that the king and the highest prelate of his realm had a conflict in the 1240s. Apart from other minor data, the royal charter issued on March 15, 1249 itself contradicts this view; the document was merely meant to perpetuate the donation of the royal castle of Esztergom to the archbishop..$^{55}$

We should not forget the charter of Innocent IV issued a few weeks prior to the mentioned assurance on November 13, 1252, which can be related to a letter sent to King Béla IV. According to the pope's decision, the tithes from the Csallóköz region (today Žitný ostrov, SK) belonged to Stephen Báncsa, and he commissioned the abbots of

\footnotetext{
49 See Zsoldos, Magyarország világi, 84 and 108. Cf. Thoroczkay, “A magyar Aachen”, 527-528; Gábor Thoroczkay, "A székesfehérvári prépostság és bazilika az Árpád-korban” [The provostry and basilica of Székesfehérvár in the Middle Ages], in: idem, Ismeretlen Árpád-kor. Püspökök, legendák, krónikák (Budapest: L'Harmattan, 2016), 179.

50 Szücs, “A kereszténység belso"”, 168.

51 Zsoldos, Magyarország világi, 107-108.

52 According to Jenő Szűcs, after his return from Rome, Stephen Báncsa was to be found in the entourage of King Béla IV in Trogir, where the monarch sought refuge before the Mongol invaders. Gergely Kiss, on the contrary, states that it is not certain whether Báncsa remained in Italy after the death of Pope Gregory IX or he returned to Hungary. Nonetheless, if Stephen Báncsa was indeed on the king's side, it could corroborate the hypothesis that by that time there was no turbulence between them. It is to be noted furthermore that Benedict was present in Trogir as well. See Szücs, "A kereszténység belso"”, 164; Kiss, Dél-Magyarországtól Itáliáig, 30.

53 Szücs, “A kereszténység belső”, 168.

54 Gergely Kiss thinks that the tension was only temporary and that the archbishop was not disfavoured after 1245. See Kiss, Dél-Magyarországtól Itáliáig, 29.

55 Regesta regum, No. 902. See with further details Kiss, Dél-Magyarországtól Itáliáig, 26.
} 
Pannonhalma and Pilis to ensure this provision. ${ }^{56}$ On December 30, Innocent IV even appointed the former archbishop as the administrator in spiritualibus et temporalibus of the archdiocese of Esztergom, perhaps to help him cover the costs of his Italian stay. The bishops of Veszprém and Vác were supposed to carry out the decision, but the king and the cathedral chapter of Esztergom were informed as well. ${ }^{57}$ This turn of events certainly did not please the monarch, as his complaint, which was sent to the pope in the following year, clearly shows it. ${ }^{58}$ The king pointed out in his longer letter written on the May 11, 1253, that the state of the archbishopric was no longer tenable and asked for the confirmation of Benedict, archbishop of Kalocsa, as the new prelate of Esztergom. ${ }^{59}$ It cannot be stated beyond doubt that the papal assurance regarding the prohibition of citing Hungarian clerics and laymen outside of the realm was connected to Stephen Báncsa's situation, yet the chronological proximity makes it presumable; especially because in our knowledge, there is no other papal measure of similar nature from this time. Thus, one cannot speak of a universal papal idea. Most probably the reason must be sought within the papal-Hungarian relations. ${ }^{60}$ It does not seem to be beyond the realm of reality either that the initiative came from Archbishop Stephen himself, or perhaps he was the one who delivered the royal supplication mentioned in the papal charter, ${ }^{61}$ if there was such a request at all. The pope's intention may have been to please the Hungarian monarch, because Innocent IV counted with his anger about the situation in Esztergom. Nevertheless, these assumptions cannot be supported by solid evidence: they are based solely on the chronology of events and on the dynamics of the judge delegate and the papal-royal connection.

Regarding the impact of the papal command, it can be stated that there was no significant hiatus in the operation of the system, which means that laymen and clergymen continued to be cited outside of the realm, and the local clerics practically acted as judges delegate in their cases. The prosecution against Bishop Job of Pécs in 1253 itself vouches for this statement; the reason was the prelate's hesitation to pay the sum previously ordered by the pope (yearly 200 silver marks) to the former bishop of Pécs, Bartholomew. ${ }^{62}$ An appeal of certain priests from the Diocese of Veszprém is also known

\footnotetext{
56 Regesta Pontificum Romanorum, No. 14769; Les registres d'Innocent IV, No. 6085. Cf. Kiss, Dél-Magyarországtól Itáliáig, 41.

57 Regesta Pontificum Romanorum, No. 14816; Les registres d'Innocent IV, No. 6165; Regesta Pontificum Romanorum, No. 14817; Les registres d'Innocent IV, No. 6166; Regesta Pontificum Romanorum, No. 14818; Les registres d'Innocent IV, No. 6167. See Kiss, Dél-Magyarországtól Itáliáig, 41.

58 Regesta regum, No. 991.

59 See Szűcs, “A kereszténység belső”, 169-170; Kiss, Dél-Magyarországtól Itáliáig, 42-43.

60 Cf. Regesta Pontificum Romanorum and Les registres d'Innocent IV.

61 Nos tuis devotis supplicationibus inclinati... - Codex diplomaticus Hungariae, IV/2, 129.

62 Regesta Pontificum Romanorum, No. 14966; Les registres d'Innocent IV, No. 6538; Regesta Pontificum Romanorum, No. 14967; Les registres d'Innocent IV, No. 6539; Regesta Pontificum Romanorum, No. 14969; Les registres d'Innocent IV, No. 6535; Codex diplomaticus Hungariae, IV/2, 181. See László Koszta, "Püspökök és városuk. A 14. század közepéig” [Bishops and their town until the mid-14th century], in: A pécsi egyházmegye története I. A középkor évszázadai (1009-1543), ed. Tamás Fedeles, Gábor Sarbak, and József Sümegi (Pécs: Fény, 2009), 81; Damian, “Eneco ferences szerzetes”, 20-21.
} 
from this period; they claimed that their opponents, the bishop, the cathedral chapter, and the archdeacons of Veszprém, same as the judge delegate, did not follow the rules of prosecution..$^{63}$ This latter example is especially worth noting, since the clerics, according to the acting subdelegates' charter, raised objections because of the legitimacy of the procedure. They claimed that the litigation went on without the pope's approval and therefore they were not able to practice their right to appeal, nor did they give their consent to the appointed judges. ${ }^{64}$ The subdelegates, on the other hand, did not give their approval to the present procurators of the priests because of the lack of their commission letters, and based on the papal charters in their possessions ordered them to obey the bishop, the chapter, and the archdeacons, and they cited them anew. ${ }^{65}$

Based on all these data, it seems plausible to argue that the assurance given to Béla IV in 1252 did not cause the pausing or ending of the operation of papal delegated jurisdiction in the realm of Hungary. But the papal charter deserves our attention from a historiographical point of view as well, since an article by the Hungarian legal historian, György Bónis, published after his death in 1997, says that Béla IV forbade his subjects to be cited outside of the realm. ${ }^{66}$ As we have seen, the text of the charter in question was not a royal prohibition, but a papal assurance given to the monarch due to his supplication. It has to be underlined, however, that Bónis's work was published originally in German in 1963, in the prominent Zeitschrift der Savigny-Stiftung für Rechtsgeschichte, Kanonische Abteilung, and it states explicitly that Béla received a guarantee for his subjects not to be cited outside of the country, a statement correlating with the text of the papal charter. ${ }^{67}$ Nonetheless, we can read in both versions that the Hungarian king, due to the pope's and his legates' disapproval, gave up the mentioned right eventually. ${ }^{68}$ The Hungarian and the German versions are identical in this case, therefore we can conclude that the previous sentence in the Hungarian

63 ... iidem sacerdotes litteras appellationis nobis optulerunt, sub hac forma... - Monumenta Romana Episcopatus Vesprimiensis, I, 134, No. CLXIII.

64 ... super litteris sine consensu domini pape, tacita veritate et suggesta falsitate emanatis, quibus nos indebite nituntur aggravare, et quod, salva appellacione et citacione nostra pendente, multa super nos sunt per ipsos innovata; (contra) huiusmodi litteras et iudices, cum non ex voluntate parcium sitis iudices delegati, et non per dominum apostolicum assignati, sed ex falsa suggestione predictarum litterarum, similiter appellamus... - Monumenta Romana Episcopatus Vesprimiensis, I, 134, No. CLXIII.

65 ... iuxta formam litterarum domini pape nobis datarum, ut venerabili patri episcopo Vesprimiensi, tamquam ordinario suo, debitam exhibeant reverenciam et honorem [...] eosdem sacerdotes ab octava beati Martini ad quindenam perhemtorie citent iterato ad nostram presenciam, mandatum apostolicum audituros... - Monumenta Romana Episcopatus Vesprimiensis, I, 134-135, No. CLXIII.

66 György Bónis, "Egyházi bíráskodás a középkori Magyarországon” [Ecclesiastical judiciary in medieval Hungary], in: idem, Szentszéki regeszták. Iratok az egyházi biráskodás történetéhez a középkori Magyarországon, ed. Elemér Balogh (Szeged: József Attila Tudományegyetem Állam- és Jogtudományi Karának tudományos bizottsága, 1997), 632. Bónis cites the above-mentioned charter of December 3, 1252. Vetera monumenta historica Hungariam sacram illustrantia I-II, ed. Augustinus Theiner (Rome, 1859-1860), I, 214, No. CCCI.

67 “... die Zusicherung, seine Untertanen nicht 'ins Ausland' zu laden.” György Bónis, “Die Entwicklung der geistlichen Gerichtsbarkeit in Ungarn vor 1526”, Zeitschrift der Savigny-Stiftung für Rechtsgeschichte. Kanonische Abteilung 49 (1963): 196.

68 Bónis, “Egyházi bíráskodás”, 632; Bónis, “Die Entwicklung”, 196. 
text was a misinterpreted translation. ${ }^{69}$ Bónis used a papal charter issued in $1259^{70}$ to support his statement regarding the king's relinquishment, which, as Bónis stated, was also meant to have an impact on the previously mentioned excommunication privilege of the monarch. ${ }^{71}$

It is crucial to underline that the Hungarian version of György Bónis's study was a posthumous translation made by the editor of the book, and it diverges on certain points from the original German text: the passage in question about King Béla IV's prohibition is one of those differences. The meaning of the sentence has been changed though - despite the formulation of the papal charter - where it reads that the Holy Father acted on the basis of a royal petition. So, we cannot speak of royal disallowance, ${ }^{72}$ but of papal allowance. Nonetheless, the statement from the Hungarian version of Bónis's paper has spread among the Hungarian historians, which is seen in the fact that it can be found in several works. ${ }^{73}$

As we have seen earlier, the prohibition of citation outside of the realm was not conclusive, at least not entirely, as several charters from the era prior to 1259 support this conclusion. The operation of delegated jurisdiction meant de iure that the litigants were cited to the papal court, outside of the realm, even if in practice this meant that the cases were administered by the local clerics acting on behalf of the papal authority. ${ }^{74}$ It is to be noted, however, that there are significantly less examples known in comparison with the period prior to 1254 . The reason behind this phenomenon is difficult to determine, and perhaps we have to consider the effects of the papal order of 1252 . If this supposition is true, then the charter is not the only source of the operation of papal courts in Hungary.

69 The German original was translated by the editor of the book, Elemér Balogh, as homage to Bónis. See Elemér Balogh, “Bevezetés [Introduction]”, in: György Bónis, Szentszéki regeszták. Iratok az egyházi bíráskodás történetéhez a középkori Magyarországon, ed. Elemér Balogh (Szeged: József Attila Tudományegyetem Állam- és Jogtudományi Karának tudományos bizottsága, 1997), 12. For a critique of the book, see the review by Norbert C. Tóth, “Bónis György: Szentszéki regeszták. Iratok az egyházi bíráskodás történetéhez a középkori Magyarországon”, Századok 134 (2000): 260-264.

70 Regesta Pontificum Romanorum, No. 17585.

71 Bónis, "Die Entwicklung", 196. According to the Hungarian text, "the king also got the right of excommunication," therefore this can likewise be considered as an imperfect translation. Bónis, "Egyházi bíráskodás”, 632. Bónis handles the privileges given to Andrew II (Regesta Pontificum Romanorum, No. 8991 and 10010; Les registres de Grégoire IX, No. 851 and 2756) and Béla IV (Regesta Pontificum Romanorum, No. 11565; Les registres d'Innocent IV, No. 1067) together. Béla IV was given the right in 1245 that those living in his territories and the territories of his family members were not to be punished with ecclesiastical censures unless it is permitted by a special papal decision.

72 Like in the case of England in the 12th century (the prohibition for laymen to bring their lawsuits to ecclesiastical courts, with the exception of matrimonial cases and testaments), or in the 13th (regarding the jurisdiction of the ecclesiastical courts there). See Sayers, Papal Judges Delegate, 220; Müller, Päpstliche Delegationsgerichtsbarkeit, 25.

73 E.g. Gergely Kiss, “Az egyházi kormányzat a középkori Magyarországon” [Ecclesiastical government in medieval Hungary], in: Magyarország kormányzati rendszere (1000-1526), eds. Márta Font, Tamás Fedeles, Gergely Kiss, and Kata Raffayné Kálsecz (Pécs: PTE, 2007), 113; Barabás, “A pápai kiküldött", 179.

74 See furthermore Regesta Pontificum Romanorum, No. 15821; Les registres d'Alexandre IV, ed. C. Bourel de la Roncière, J. de Loye, and A. Coulon (Paris, 1901-1953), No. 435. 
Two papal charters from 1254 shed some light on the situation in the Hungarian realm. Pope Innocent IV gave privileges to two Hungarian prelates, which concerned the jurisdiction of the Apostolic See and its agents. ${ }^{75}$ Bishop Philip of Zagreb received the insurance that he could be cited to the Holy See solely with a special permission of the pope ${ }^{76}$ meanwhile Archbishop Benedict of Esztergom and the chapter of his seat were reassured that no papal delegate, subdelegate, executor, or conservator would engage in ecclesiastical censures (supsensio, interdictum or excommunication) against them, unless there was a prior permission from the Apostolic See. ${ }^{77}$ In the latter case, Innocent IV appointed conservators as well. The task of the abbots of Pilis and Zirc was to act on behalf of the archbishop in case someone was trying to engage in ecclesiastical censure against him despite the papal decision. ${ }^{78}$

There are several differences between the two charters. In the case of Bishop Philip of Zagreb, there is a passage in the text - similar to the diploma sent to Béla IV in the end of 1252 - that the cause of the measure was the former petition of the recipient, therefore the initiative was not to be sought on the papal side. ${ }^{79}$ On the contrary, Archbishop Benedict received the privilege not ad personam, but alongside his cathedral chapter and including the whole church of Esztergom. ${ }^{80}$ The latter case differs also in that it does not mention the initiative of the privileged prelate or his church: the privilege was justified with the special respect that the archbishop and the chapter

75 Archbishop Robert of Esztergom received a similar privilege in 1235: ... attendentes, tuis devotis precibus, quantum cum Domino et honestate possumus, duximus benignius annuendum. Inde est, quod nos etati tue paterno compatientes affectu, ne quis in personam tuam sine speciali mandato nostro, preter legatum a nostro latere destinatum, excommunicationis vel suspensionis sententiam valeat promulgare, auctoritate tibi presentium indulgemus... - Árpádkori új okmánytár - Codex diplomaticus Arpadianus continuatus. I-XII, ed. Gusztáv Wenzel (Pest and Budapest, 1860-1874), II, 31, No. 6; Regesta Pontificum Romanorum, No. 10049.

76 ... si te ad instantiam alicuius per litteras apostolicas citari contigerit: quod compareas coram nobis, venire propter hoc ad apostolicam sedem nullatenus tenearis; nisi eedem littere de indulto huiusmodi plenam et expressam fecerint mentionem... - Codex diplomaticus Hungariae, IV/2, 251; Regesta Pontificum Romanorum, No. 15463; Les registres d'Innocent IV, No. 7895.

77 ...nullus delegatus, (vel) subdelegatus, executor, aut etiam conservator, auctoritate Sedis apostolice, vel legatorum ipsius in nos, vel ecclesxiam vestram excommunicationis, suspensionis, vel interdicti sentenitas promulgare, aut interdicere vobis ingressum ecclesie (va)leat, absque speciali mandato Sedis eiusdem, faciente plenam et expressam de hac indulgentia mentionem... - Árpádkori új okmánytár, VII, 367, No. 256; Regesta Pontificum Romanorum, No. 15537. Cf. Esztergomi érsekek. 113.

78 Quoirca discretioni vestre pcr apostolica scripta mandamus, quatenus dictos archiepicopum, capitulum et ecclesiam non permittatis super hijs contra concessionis nostre tenorem ab aliquibus indebite molestare; molestatores huiusmodi per censuram ecclesiasticam, appellacione postposita, compescendo; non obstante, si aliquibus, quod excommunicari, suspendi, vel interdici, aut conveniri extra certa loca non valeant, a Sede apostolica sit indultum, et constitutione de duabus dietis, edita in concilio generali... - Árpádkori új okmánytár, VII, 368-369, No. 257; Regesta Pontificum Romanorum, No. 15538.

79 Hinc est, quod nos tuis supplicationibus inclinati, auctoritate tibi presentium indulgemus... - Codex diplomaticus Hungariae, IV/2, 251; Regesta Pontificum Romanorum, No. 15463; Les registres d'Innocent $I V$, No. 7895.

80 ... ut si te ad instantiam alicuius per litteras apostolicas citari contigerit... - Codex diplomaticus Hungariae, IV/2, 251; ... archiepiscopo et dilectis filijs capitulo Strigoniensi... in vos, vel ecclesiam vestram... - Árpádkori új okmánytár, VII, 367, No. 256. 
showed for the Apostolic See.$^{81}$ Furthermore, it is worth mentioning that eight decades later, in the 1330s, Archbishop Csanád Telegdi of Esztergom, in his quarrel with the bishop of Cracow regarding the jurisdiction over certain villages in the Scepus region (in Hungarian Szepesség, Spiš, SK), referred to the measure of Innocent IV. The archbishop called on the abbots of Pilis and Pannonhalma to prevent the application of ecclesiastical censures against him. ${ }^{82}$

It should not be forgotten either that a few days before the assurance was given to the archbishop of Esztergom, on September 29, 1254, the chapter of Meissen in Saxony received the same privilege, only with a limited time frame, for three years. Nonetheless, the former petition of the chapter of Meissen is mentioned in the charter, ${ }^{83}$ therefore it cannot be stated with absolute certainty that the measure refers to a consistent papal policy. Yet, the chronological proximity and the similarities in the formulations of the charters allow us to assume that the pope granted privileges to the Archbishopric of Esztergom - among others - on the example of Meissen (or that it might have influenced the Esztergom privilege), considering the unstable state due to the struggle around Cardinal Stephen Báncsa in 1252.

It is to be noted that papal measures of such nature were no novelties in the papal-Hungarian relations. Archbishop Benedict, as the provost of Fehérvár, received a similar assurance for himself and his church as early as June 1241, and it gave him an immunity of citations before the papal court for the time of the Mongol invasion. ${ }^{84}$ The bishop of Zagreb, Stephan ${ }^{85}$ - similar to the later privilege for Esztergom - received in April 1246 a dispensation of ecclesiastical censures applied by the papal delegates against him and his church. ${ }^{86}$ The provost and chapter of Esztergom were given a papal permission in July 1247 stating that they were allowed to hold masses even in times of general interdict. ${ }^{87}$

\footnotetext{
81 Apostolice Sedis benignitas sincere obsequentium vota fidelium favore benivolo proseqni consuevit, et personas illorum, quos in sua devotione promptos inueverit et ferventes, quibusdam (titulis) decentius decorare. Ut igitur ex speciali devotione, quam ad nos et Romanam ecclesiam habere noscimini... Árpádkori új okmánytár, VII, 367, No. 256.

82 I am grateful to Ágnes Maléth for the data. See Ágnes Maléth, A Magyar Királyság és a Szentszék kapcsolata I. Károly korában (1301-1342) [The relations between the Kingdom of Hungary and the Holy See under the reign of King Charles I (1301-1342)] (Pécs: PTE BTK TTI Középkori és Koraújkori Történeti Tanszék, 2020 - forthcoming).

83 Hinc est quod nos vestris supplicationibus inclinati vobis auctoritate presentium indulgemus, ut nullus delegatus vel subdelegatus ab eo executor seu etiam conservator auctoritate litterarum Sedis apostolice vel legatorum ipsius possit in vos excommunicationis, suspensionis vel interdicti sententiam promulgare absque speciali eiusdem sedis mandato... presentibus post triennium minime valituris... - Codex diplomaticus Saxoniae Regiae. Zweiter Hauptteil. 1. Band. Urkunden des Hochstifts Meissen Band I, ed. Ernst Gotthelf Gersdorf (Leipzig 1864), 145, No. 177; Regesta Pontificum Romanorum, No. 15532.

84 Regesta Pontificum Romanorum, No. 11036; Les registres de Grégoire IX, No. 6055. See Thoroczkay, "A magyar Aachen", 535.

85 Zsoldos, Magyarország világi archontológiája, 102.

86 Regesta Pontificum Romanorum, No. 12077. A few days later, the bishop was allowed to be absent from the general council. Regesta Pontificum Romanorum, No. 12092.

87 Regesta Pontificum Romanorum, No. 12628.
} 
Another charter of Innocent IV can be linked to our investigation as well. On April 24, 1254, the pope commissioned Archbishop Benedict to help Gerhard of Parma, canon of Esztergom and the chaplain of Cardinal Stephen Báncsa, to receive a further benefice in the Hungarian Church. ${ }^{88}$ This was not the first mandate in this affair. One year earlier, the bishop of Györ was already ordered to do so. ${ }^{89}$ According to the charter, Gerhard was not to be punished with ecclesiastical censures or be cited outside of his diocese without the permission of the Apostolic See..$^{0}$ These data confirm the hypothesis that the above-mentioned charters can be understood as a type of papal favour.

The privileges given to the archbishop and the bishop are also interrelated from another point of view, in terms of their individual beneficiaries, even though they covered different rights. Philip and Benedict both belonged to the inner circle of King Béla IV; the latter's role has already been discussed, whereas the bishop of Zagreb, as a member of the prominent Türje genus, had been raised in the royal court and later became provost of Dömös before his title as the bishop of Zagreb, and finally he was elected to the archbishopric of Esztergom after the death of Benedict. ${ }^{91}$ Therefore, they were the supporters of the king, aiding him in his endeavours. ${ }^{92}$ Based on these documents and the charter given to the king in 1252, it might be assumed that Béla IV personally played a role in the papal decisions regarding the bishop of Zagreb and the archbishopric of Esztergom, but there is no source confirming this assumption and it would also seem rather unrealistic.

In the case of Philip, it is of crucial importance that he visited the papal court in 1254 as the emissary of the Hungarian monarch alongside the Franciscan Ecce. His mission was related to Béla IV's conflict with the Bohemian king, Ottokar II (1253 -

\footnotetext{
88 Regesta Pontificum Romanorum, No. 15344; Les registres d'Innocent IV, No. 7741. For Gerhard, see Dániel Bácsatyai, "Személyi összeköttetések a Curia Romana és a magyar egyház között a 13. század közepén. Pármai Albert és Báncsa István” [Personal relations between the Curia Romana and the Hungarian Church in the mid-13th century: Albert of Parma and István Báncsa], Történelmi Szemle 60 (2018): 306; Gábor Barabás, "Papal Clerics in Thirteenth-Century Hungary: Papal Delegations and Local Careers”, Krakowskie Studia z Historii Państwa i Prawa 12 (2019): 309.

89 Regesta Pontificum Romanorum, No. 14846; Les registres d'Innocent IV, No. 6710. Cf. Kiss, Dél-Magyarországtól Itáliáig, 75-76; Bácsatyai, “Személyi összeköttetések”, 306.

90 ... quod excommunicari, suspendi seu interdici, vel ad receptionem seu provisionem cuiusquam compelli, seu extra suam diocesim vel ultra certum locum ad iudicium evocari non possint per litteras dicte Sedis, non facientes plenam vel expressam de verbo ad verbum de indulgentia huiusmodi sive personarum, dignitatum numero vel receptorum nominibus mentionem... - Árpádkori új okmánytár, II, 234 , No. 156. In the second charter, the right belongs not only to Gerhard ... quod excommunicari, suspendi, vel interdici, aut conveniri extra certa loca, vel compelli ad receptionom vel provisionem alicuius non valeant a Sede apostolica, sit indultum; et universis indulgentiis vel litteris apostolicis generalibus vel specialibus, sub quacunque forma verborum obtentis et obtinendis; et quibuslibet aliis, per id impediri vel differri valeat, et de quibus seu predictorum priuilegiorum, indulgentiarum, et litterarum totis tenoribus de verbo ad verbum plenam et expressam fieri oporteat in presentibus mentionem... - Codex diplomaticus Hungariae, IV/2, 248.

91 Szűcs, "A kereszténység belső”, 164 and 168; Zsoldos, Magyarország világi, 81 and 103.

92 Szűcs, “A kereszténység belső”, 173.
} 
1278). ${ }^{93}$ This was a perfect occasion for the Hungarian ruler to present his supplication to Innocent IV. The papal charter was issued five days after the diploma was sent to the papal legate Bernhard, elected archbishop of Naples, ${ }^{94}$ which mentioned the royal delegates; therefore, Philip was probably still present in the Curia at that time.

The question raises further issues, namely: if it was indeed prohibited to cite Hungarian laymen and clergymen outside of the realm according to the assurance granted to the king, what was the purpose of the privileges given to the prelates? It is impossible to give a definitive answer to this, yet I believe these ordinations prove that despite Innocent IV's charter, we cannot speak of a caesura in citations to the papal court after 1252.

Pope Innocent IV died on December 7, 1254, two months after the privilege was given to the archbishop of Esztergom. His successor, Alexander IV, was elected five days later, on December $12 .{ }^{95}$ As we have already mentioned, György Bónis linked the withdrawal of the privilege of 1252 granted to Béla IV to the charter of Alexander IV issued in $1259 .{ }^{96}$ With this document, the archbishop of Esztergom received the assignment to cite Béla IV, on pain of excommunication, for the - lack of - fulfilment of the promises that the former monarch, Andrew II, had given to the Knights Hospitaller whilst participating in a crusade to the Holy Land. ${ }^{97}$ The diploma surely contradicts the privilege of Innocent IV given to Béla IV, but there is no passage in the 1259 charter that refers to a previous papal decision, therefore we would rather not speak of a withdrawal. ${ }^{98}$

93 Venerabilis frater noster... Zagrabiensis episcopus et dilectus filius fr. Ecce de ordine Minorum, postquam discessisti a nobis, ad sedem Apostolicam accedentes, ex parte carissimi in Christo filii nostri... regis Ungarie illustris nobis exponere curaverunt... - Vetera monumenta historica, I, 228, No. CCCCXXXV; Regesta Pontificum Romanorum, No. 15460; Les registres d'Innocent IV, No. 8309. See Szűcs, “A kereszténység belső", 172. Cf. Jenő Szűcs, Az utolsó Árpádok [The last Árpáds] (Budapest: MTA TTI, 1993), 83-84.

94 Regesta Pontificum Romanorum, No. 15460; Les registres d'Innocent IV, No. 8309. With further literature, see: http://delegatonline.pte.hu/search/persondatasheet/id/126 (last accessed on February 29, 2020).

95 Regesta Pontificum Romanorum, 1283 and 1286.

96 Regesta Pontificum Romanorum, No. 17585. Cf. Bónis, “Die Entwicklung”, 196; Bónis, "Egyházi bíráskodás”, 632 .

97 Si vero celsitudo regia premissa, quod non concedimus, omiserit adimplere, [...] ipsum peremtorie citamus, ut infra tres menses, premissos alios tres immediate sequentes, per procuratorem idoneum apostolico se conspectui representet, facturus et recepturus super premissis, quod ordo dictaverit rationisquo circa fraternitati tue per apostolica scripta sub poena excommunicationis, quam ipso facto te incurrere volumus, si mandatum nostrum in hac parte adimpletum non fueris executus, firmiter precipiendo mandamus, quatetenus eidem regi ex parte nostra easdem litteras representans, ipsum ad perficiendum et complendum, que in eisdem continentur litteris, monere ac efficaciter inducere non postponas; nobis, quid super hoc tu et nominatus rex feceritis, per litteras tuas, harum et ipsarum litterarum, eidem regi directarum, seriem continentes, infra sex menses post receptionem presentium, fideliter relaturus... Vetera monumenta historica, I, 238, No. CCCCLIII. Cf. Zsolt Hunyadi, The Hospitallers in the Medieval Kingdom of Hungary c. 1150-1387 (Budapest: METEM and CEU Press, 2010), 35. It is to be noted that the threat of excommunication affected the archbishop, not the king. Cf. Bónis, "Die Entwicklung", 196, n. 75 and Bónis, "Egyházi bíráskodás”, 632, n. 75.

98 “... die aber beide nach Gutdünken des Papstes und seiner Legaten beseitigt wurden.” Bónis, "Die Entwicklung”, 196. 
If we take a look at the period between 1252 and 1259, the years of the two papal charters in question, there are several traces of the operation of delegated jurisdiction, and those litigations were addressed de iure outside of the realm, because the judges delegate were empowered by the papal authority. ${ }^{99}$ Nevertheless, only two relevant cases are known to us from the time between 1255 and 1259. Alexander IV confirmed in April 1255 the judge delegate's former decision in the litigation of the rectors and vicars of the diocese of Eger with their local bishop and cathedral chapter due to the request of the priests. ${ }^{100}$ The practice, namely to turn to the papacy as the highest court of judgement, had not vanished completely. However, the next information from 1257 is indirectly connected to the abovementioned three papal decisions. Alexander IV decided on July 7 that Archbishop Benedict of Esztergom was not obliged to answer the citation of the bishop of Zagreb, even if he was called to do so in an apostolic letter. ${ }^{101}$ In this case, the bishop cited the archbishop, who previously had received the right not to be cited by anyone without a special permission of the Apostolic See, while Archbishop Benedict and his chapter got immunity from previous ecclesiastical censures; but in this specific affair, he was excused from answering the citation due to the pope's decision.

The relative lack of evidence regarding the operation of papal jurisdiction does not mean that there were no litigations in the Hungarian Church. Probably the quarrels did not reach that level, as among other sources the charter of the chapter of Györ reports on the activity of arbiters in the litigation between the abbeys of Pannonhalma and Zselicszentjakab, ${ }^{102}$ and King Béla IV also made a judgement in favour of Bishop Philip of Zagreb in his quarrel with certain laymen in $1259 .{ }^{103}$

The next relevant papal source derives from September 1261, when Alexander IV delegated new judges in the litigation between the abbey of Pannonhalma and the Knights Hospitaller of Csurgó. ${ }^{104}$ From the same year, we have knowledge of a continued lawsuit between Pannonhalma and the chapter of Fehérvár, and a quarrel of the same abbey with the chapter of Veszprém. ${ }^{105}$ If we continued this enumeration

\footnotetext{
99 See with further literature: Barabás, “A pápai kiküldött”, 175-176.

100 Nos itaque vestris supplicationibus inclinati, huiusmodi processum et ordinationem, sicut per eosdem iudices provide facti sunt, ratos et firmos habentes, eos auctoritate Apostolica confirmamus, et presentis scripti patrocinio communimus... - Árpádkori új okmánytár, VII, 391, No. 278; Regesta Pontificum Romanorum, No. 15821; Les registres d'Alexandre IV, No. 435.

101 ... auctoritate tibi presentium indulgemus, ut per litteras in forma comissionis vel executionis seu conservationis, super quibuscunque rebus ab apostolica Sede obtentas vel obtinendas, que de hoc indulto expressam non facerent mentionem, coram venerabili fratre nostro... Zagrabiensi episcopo, cum ipsum habeas, ut asseris, certa ratione suspectum, convenire non valeas, nec respondere tenearis invitus... Árpádkori új okmánytár, II, 287, No. 194; Regesta Pontificum Romanorum, No. 16917; Les registres d'Alexandre IV, No. 2055.

102 Árpádkori új okmánytár, II, 309, No. 212.

103 Regesta regum, No. 1221. See furthermore e.g. Regesta regum, No. 1075 and 1086.

104 Regesta Pontificum Romanorum, No. 18128.

105 Regesta Pontificum Romanorum, No. 18138 and 18139.
} 
with further data, ${ }^{106}$ it could be stated that after the relapse of the previous decade and its structural changes, there was an increase in the number of identifiable cases, at least until 1264, i.e., the war between King Béla IV and his eldest son, later Stephen $\mathrm{V}\left(1270\right.$ - 1272) ${ }^{107}$ Therefore, it is not surprising that there are no sources from 1265 , the year of open warfare, which may confirm the operation of judges delegate, and only a handful of examples are known also from the following year. ${ }^{108}$ The inquisition against Bishop Job of Pécs in 1266, ordered by Clement IV (1265-1268) has to be mentioned though (certain members of the local chapter had made a complaint against Job because of violent crimes and simony, among other things), because according to certain scholars, the reason behind this was the conflict within the royal family, since the prelate was a known supporter of the younger king. ${ }^{109}$

$* * *$

Based on the remaining data, it can be stated that the years 1241-1243 - because of the sedis vacantia and above all because of the Mongol invasion - marked a caesura in the operation of papal delegated jurisdiction in Hungary, yet we cannot speak of a real structural modification from 1243 on: as it has been demonstrated above, this was the time of the re-emergence of the former tendencies, including the continuation of previously started litigations. Nevertheless, in the 1250s, not a complete, but a tangible transition of the system can be observed. In this light, the conclusion of György Bónis regarding the ordinance of 1252 - especially the Hungarian version of it - should be modified, since we cannot speak of an absolute prohibition either from the royal or from the papal side. The number of lawsuits administered by the judges' delegate decreased though. The provisions of Innocent IV given to the archbishop of Esztergom and the bishop of Zagreb in 1254 contradict the above-mentioned hypothesis as well, since in case of a prohibition, the prelates would not have needed the privileges. Pope Innocent IV, indeed, had a share in the decline of delegated jurisdiction in the Hungarian realm, probably because of the king's or Cardinal Stephen Báncsa's initiative, but the situation seems to be far more complicated than that.

\footnotetext{
106 Regesta Pontificum Romanorum, No. 18659; Regesta Pontificum Romanorum, No. 18682; Les registres d'Urbain IV (1261-1264). Recueil des bulles de ce pape, ed. Jean Guiraud (Paris, 1899-1929), No. 1162; Regesta Pontificum Romanorum, No. 18711; Les registres d'Urbain IV, No. 939; Regesta Pontificum Romanorum, No. 18761; Les registres d'Urbain IV, No. 960; Regesta Pontificum Romanorum, No. 18787; Les registres d'Urbain $I V$, No. 489; etc.

107 For the conflict, see Attila Zsoldos, Családi ügy. IV. Béla és István ifjabb király viszálya az 1260-as években [A family affair: The conflict between King Béla IV and Stephen, the King Junior, in the 1260s] (Budapest: MTA TTI, 2007).

108 Decline can also be observed in Scotland, which Paul Ferguson has explained by the weakening of the papal power rather than the thriving of the lay courts. Paul Ferguson, Medieval Papal Representatives in Scotland: Legates, Nuncios and Judges-Delegate 1125-1286 (Edinburgh: The Scott Society, 1997), 160-190; cf. Barbara Bombi, "The Role of Judges Delegate in England: The Dispute between the Archbishops of Canterbury St. Augustine's Abbey in the Thirteenth Century”, in: Legati e delegati papali; profili, ambiti d'azione e tipologie di intervento nei secoli XII-XIII, ed. Maria Pia Alberzoni and Claudia Zey (Milan: Vita e Pensiero, 2012), 223.

109 Damian, "Eneco ferences szerzetes", 29-30.
} 


\section{Sources}

Árpádkori új okmánytár - Codex diplomaticus Arpadianus continuatus. I-XII, ed. Gusztáv Wenzel. Pest; Budapest, 1860-1874.

Codex diplomaticus Hungariae ecclesiasticus ac civilis I-XI, ed. Georgius Fejér. Buda, 1829-1844.

Codex diplomaticus Saxoniae Regiae. Zweiter Hauptteil. Urkunden des Hochstifts Meissen. Band I, ed. Ernst Gotthelf Gersdorf. Leipzig, 1864.

Les registres d'Innocent IV. I-IV, ed. Élie Berger. Paris, 1881-1919.

Les registres d'Alexandre IV, ed. C. Bourel de la Roncière, J. de Loye, and A. Coulon. Paris, 1901-1953.

Les registres d'Urbain IV (1261-1264). Recueil des bulles de ce pape, ed. Jean Guiraud. Paris, 1899-1929.

Les registres de Grégoire IX. Recueil des bulles de ce pape publiées et analysées d'après les manuscrits originaux du Vatican par Lucien Auvray, t. I-IV. Paris, 1890-1955.

Magistri Rogerii, Epistola in miserabile carmen super destructione regni Hungariae per Tartaros facta, translated and annoted by János M. Bak and Martin Rady. Budapest; New York, 2010.

Monumenta Romana Episcopatus Vesprimiensis - A veszprémi püspökség római oklevéltára. I-IV, ed. Vilmos Fraknói and József Lukcsics. Budapest, 1896-1907.

Regesta Pontificum Romanorum inde ab anno post Christum Natum MCXCVIII ad annum MCCCIV, ed. August Potthast. Berlin, 1874.

Regesta regum stirpis Arpadianae critico-diplomatica - Az Árpád-házi királyok okleveleinek kritikai jegyzéke, ed. Imre Szentpétery and Iván Borsa. Budapest, 1923-1943.

Thomae archidiaconi Spalatensis Historia Salonitanorum atque Spalatinorum pontificum. Archdeacon Thomas of Split, History of the Bishops of Salona and Split, ed. Olga Perić, Damir Karbić, Mirjana Matijević Sokol, and James Ross Sweeney. Budapest and New York: CEU Press, 2006.

Vetera monumenta historica Hungariam sacram illustrantia I-II, ed. Augustinus Theiner. Rome, 1859-1860.

\section{Secondary Literature}

Almási, Tibor. "Egy ciszterci bíboros a pápai világhatalom szolgálatában. Pecorari Jakab magyarországi legációja”. Magyar Egyháztörténeti Vázlatok 5 (1993): 129-141.

Almási, Tibor. “Megjegyzések Rogerius magyarországi méltóságviseléséhez”. Acta Universitatis Szegediensis de Attila József nominate. Acta Historica 86 (1988): 9-14.

Bácsatyai, Dániel. "Személyi összeköttetések a Curia Romana és a magyar egyház között a 13. század közepén. Pármai Albert és Báncsa István”. Történelmi Szemle 60 (2018): 299323.

Balogh, Elemér. "Bevezetés”. In: György Bónis, Szentszéki regeszták. Iratok az egyházi bíráskodás történetéhez a középkori Magyarországon, ed. Elemér Balogh, 9-12. Szeged: 
József Attila Tudományegyetem Állam- és Jogtudományi Karának tudományos bizottsága, 1997.

Barabás, Gábor. “A középkori pápai delegáltbíróság nemzetközi és magyar kutatástörténete”. Egyháztörténeti Szemle 20 (2019): 3-23.

Barabás, Gábor. “A pápai kiküldött bíráskodás Magyarországon a kezdetektől a 13. század közepéig”. Történelmi Szemle 55 (2013): 175-199.

Barabás, Gábor. "Heretics, Pirates, and Legates. The Bosnian Heresy, the Hungarian Kingdom, and the Popes in the Early 13th Century". Specimina Nova Pars Prima Sectio Mediaevalis 9 (2017): 35-58.

Barabás, Gábor. "Papal Clerics in Thirteenth-Century Hungary: Papal Delegations and Local Careers". Krakowskie Studia z Historii Państwa i Prawa 12 (2019): 293-318.

Barabás, Gábor. Das Papsttum und Ungarn in der ersten Hälfte des 13. Jahrhunderts (ca. 1198 - ca. 1241). Päpstliche Einflussnahme - Zusammenwirken - Interessengegensätze. Vienna: Institut für Ungarische Geschichtsforschung in Wien; Balassi Institut - Collegium Hungaricum Wien; Ungarische Archivdelegation beim Haus-, Hof- und Staatsarchiv, 2014.

Bombi, Barbara. "The Role of Judges Delegate in England: The Dispute between the Archbishops of Canterbury St. Augustine's Abbey in the Thirteenth Century”. In: Legati e delegati papali; profili, ambiti d'azione e tipologie di intervento nei secoli XII-XIII, ed. Maria Pia Alberzoni and Claudia Zey, 221-260. Milan: Vita e Pensiero, 2012.

Bónis, György. "Die Entwicklung der geistlichen Gerichtsbarkeit in Ungarn vor 1526”. Zeitschrift der Savigny-Stiftung für Rechtsgeschichte. Kanonische Abteilung 49 (1963): 174235.

Bónis, György. “Egyházi bíráskodás a középkori Magyarországon”. In: Szentszéki regeszták. Iratok az egyházi biráskodás történetéhez a középkori Magyarországon, ed Elemér Balogh, 621-658. Szeged: József Attila Tudományegyetem Állam- és Jogtudományi Karának tudományos bizottsága, 1997.

Csóka, Gáspár. “Liber ruber”. In: Korai Magyar Történeti Lexikon, ed. Gyula Kristó, Pál Engel, and Ferenc Makk. Budapest: Akadémiai Kiadó, 1994.

Damian, Iulian Mihai. “Eneco ferences szerzetes inquisitiója Pécs püspökével szemben (1267)”. Egyháztörténeti Szemle 17 (2016), No. 2: 19-38.

Duggan, Charles. "Papal Judges Delegate and the Making of the 'New Law' in the Twelfth Century". In: idem, Decretals and the Creation of "New Law" in the Twelfth Century: Judges, Judgements, Equity, and Law, 172-199. Aldershot; Brookfield; Singapore; Sydney: Ashgate, 1998.

Engel, Frank. "Die Diözese Ávila und die päpstliche Delegationsgerichtsbarkeit im 12. Jahrhundert”. In: Das begrenzte Papsttum. Spielräume päpstlichen Handelns Legaten - delegierte Richter - Grenzen, ed. Klaus Herbers, Fernando López Alsina, and Frank Engel, 289-309. Berlin; Boston: De Gruyter, 2013.

Esztergomi érsekek. 1001-2003, ed. Margit Beke. Budapest: Szent István Társulat, 2003. 
Falkenstein, Ludwig. "Appellationen an den Papst und Delegationsgerichtsbarkeit am Beispiel Alexanders III. und Heinrichs von Frankreich". Zeitschrift der Kirchengeschichte 97 (1986): 36-65.

Ferguson, Paul. Medieval Papal Representatives in Scotland: Legates, Nuncios and Judges-Delegate 1125-1286. Edinburgh: The Scott Society, 1997.

Hageneder, Othmar. Die geistliche Gerichtsbarkeit in Ober- und Niederösterreich. Von den Anfängen bis zum Beginn des 15. Jahrhunderts. Linz: Hermann Böhlaus Nachf., 1967.

Herbers, Klaus. Geschichte des Papsttums im Mittelalter. Darmstadt: WBG, 2012.

Herde, Peter. "Zur päpstlichen Delegationsgerichtsbarkeit im Mittelalter und in der frühen Neuzeit”. Zeitschrift der Savigny-Stiftung für Rechtsgeschichte. Kanonische Abteilung 119 (2002): 20-43.

Holndonner, Andreas. Kommunikation - Jurisdiktion - Integration Das Papsttum und das Erzbistum Toledo im 12. Jahrhundert (ca. 1085 - ca. 1185). Berlin; Munich; Boston: De Gruyter, 2014.

Horváth, Richárd. “A favár rejtélye, avagy mennyire régi Újvár vára?: Németújvár várának 'vélelmezett' története a kezdetektől a 13. század végéig”. Castrum - A Castrum Bene Egyesület Hírlevele 18 (2015): 5-24.

Hunyadi, Zsolt. The Hospitallers in the Medieval Kingdom of Hungary c. 1150-1387. Budapest: METEM; CEU Press, 2010.

Johrendt, Jochen; Müller, Harald. "Zentrum und Peripherie. Prozesse des Austausches, der Durchdringung und der Zentralisierung der lateinischen Kirche im Hochmittelalter". In: Römisches Zentrum und kirchliche Peripherie. Das universale Papsttum als Bezugspunkt der Kirchen von den Reformpäpsten bis zu Innozenz III., ed. Jochen Johrendt and Harald Müller, 1-16. Berlin; New York: De Gruyter, 2008.

Kéry, Lotte. "Dekretalenrecht zwischen Zentrale und Peripherie”. In: Römisches Zentrum und kirchliche Peripherie. Das universale Papsttum als Bezugspunkt der Kirchen von den Reformpäpsten bis zu Innozenz III., ed. Jochen Johrendt and Harald Müller, 19-45. Berlin; New York: De Gruyter, 2008.

Kiss, Gábor. "A conservatores hivatala, mint a pápai küldöttbíráskodás sajátos megjelenése az érett középkorban”. Fons 22 (2015): 91-102.

Kiss, Gergely. “A pápai képviselet”. In: Varietas delectat A pápai-magyar kapcsolatok sokszínüsége a 11-14. században, ed. Gergely Kiss, 11-57. Pécs: PTE BTK TTI, 2019.

Kiss, Gergely. “Az egyházi kormányzat a középkori Magyarországon”. In: Magyarország kormányzati rendszere (1000-1526), ed. Márta Font, Tamás Fedeles, Gergely Kiss, and Kata Raffayné Kálsecz, 101-136. Pécs: PTE, 2007.

Kiss, Gergely. Dél-Magyarországtól Itáliáig. Báncsa nembeli István (1205 k. - 1270) váci püspök, esztergomi érsek, az első magyarországi bíboros életpályája. Pécs: Kronosz, 2015.

Koszta, László. "Egy francia származású főpap Magyarországon. Bertalan pécsi püspök (1219-1251)”. In: Irásbeliség és egyházszervezet. Fejezetek a középkori magyar egyház történetéből, 23-44 (Capitukum III.). Szeged: Szegedi Egyetemi Kiadó, 2007. 
Koszta, László. "Püspökök és városuk. A 14. század közepéig”. In: A pécsi egyházmegye története I. A középkor évszázadai (1009-1543), ed. Tamás Fedeles, Gábor Sarbak, and József Sümegi, 57-107. Pécs: Fény, 2009.

Laszlovszky, József; Pow, Stephen; Romhányi, Beatrix F.; Ferenczi, László; Pinke, Zsolt. "Contextualizing the Mongol Invasion of Hungary in 1241-42: Short- and Long-Term Perspectives”. Hungarian Historical Review 7 (2018): 419-450.

Maléth, Ágnes. A Magyar Királyság és a Szentszék kapcsolata I. Károly korában (13011342). Pécs: PTE BTK TTI Középkori és Koraújkori Történeti Tanszék, 2020.

Müller, Harald. "Entscheidung auf Nachfrage. Die delegierten Richter als Verbindungsglieder zwischen Kurie und Region sowie als Gradmesser päpstlicher Autorität”. In: Römisches Zentrum und kirchliche Peripherie. Das universale Papsttum als Bezugspunkt der Kirchen von den Reformpäpsten bis zu Innozenz III., ed. Jochen Johrendt and Harald Müller, 108-131. Berlin; New York: De Gruyter, 2008.

Müller, Harald. Päpstliche Delegationsgerichtsbarkeit in der Normandie (12. und frühes 13. Jahrhundert). Bonn: Bouvier Verlag, 1997.

Ott, John S. "Men on the Move: Papal Judges-Delegate in the Province of Reims in the Early Twelfth Century”. In: The Use of Canon Law in Ecclesiastical Administration, 10001234, ed. Melodie H. Eichbauer and Danica Summerlin, 23-50. Leiden; Boston: Brill, 2019.

Pavloff, George, G. Papal Judge Delegates at the Time of the Corpus Iuris Canonici. Washington, DC: The Catholic University of America Press, 1963.

Rabić, Nedim. "Im toten Winkel der Geschichte: Johannes von Wildeshausen als Bischof von Bosnien 1233/34-1237”. In: Die deutschen Dominikaner und Dominikanerinnen im Mittelalter, ed. Sabine Heusinger, Elias H. Füllenbach, Walter Senner, and Klaus-Bernward Springer, 53-69. Berlin; Boston: De Gruyter, 2016.

Sayers, Jane E. Papal Judges Delegate in the Province of Canterbury 1198-1254: A Study in Ecclesiastical Jurisdiction and Administration. Oxford: Oxford University Press, 1971.

Schrör, Matthias. Metropolitangewalt und papstgeschichtliche Wende. Husum: Matthiesen Verlag, 2009.

Senga, Toru. “IV. Béla külpolitikája és IV. Ince pápához intézett 'tatár-levele”. Századok 121 (1987): 584-612.

Smith, Thomas W. "Papal Executors and the Veracity of Petitions from Thirteenth-Century England”. Revue d'Histoire Ecclésiastique 110 (2015): 662-683.

Sweeney, James Ross. "Innocent III, Canon Law and Papal Judges Delegate in Hungary". In: Popes, Teachers, and Canon Law in the Middle Ages, ed. James Ross Sweeney and Stanley Chodorow, 26-51. Ithaca; New York: Cornell University Press, 1989.

Szücs, Jenő. “A kereszténység belső politikuma a XIII. század derekán. IV. Béla és az egyház”. Történelmi Szemle 21 (1978): 158-181.

Szücs, Jenő. Az utolsó Árpádok. Budapest: MTA TTI, 1993.

Ternovácz, Bálint. “A boszniai latin püspökség története 1344-ig”. In: Micae Mediaevales V. Fiatal történészek dolgozatai a középkori Magyarországról és Európáról, ed. Laura 
Fábián, Judit Gál, Péter Haraszti Szabó, and Dorottya Uhrin, 215-228. Budapest: ELTE BTK Történelemtudományi Doktori Iskola , 2016.

Thoroczkay, Gábor. “A székesfehérvári prépostság és bazilika az Árpád-korban”. In: idem, Ismeretlen Árpád-kor. Püspökök, legendák, krónikák, 141-183. Budapest: L’Harmattan, 2016.

Thoroczkay, Gábor. “A magyar Aachen első évszázada: a székesfehérvári prépostság története az Árpád-korban.” In: Szent Márton és Benedek nyomában. Tanulmányok Koszta László emlékére, ed. Tamás Fedeles and Zsolt Hunyadi, 522-539. Szeged; Debrecen: FIKP “Magyarország a középkori Európában” - Szegedi Tudományegyetem Középkori és Kora Újkori Magyar Történeti Tanszék, 2019.

Udvardy, József. A kalocsai érsekek életrajza (1000-1526). Cologne: Görres Gesellschaft, 1991.

Zsoldos, Attila. Családi ügy. IV. Béla és István ifjabb király viszálya az 1260-as években. Budapest: MTA TTI, 2007.

Zsoldos, Attila. Magyarország világi archontológiája. 1000-1301. Budapest: MTA TTI, 2011. 


\section{Gábor Barabás*}

\section{Nos tuis supplicationibus inclinati: papa Inocent IV. i pad delegirane juris- dikcije u Ugarskoj sredinom 13. stoljeća}

\section{Sažetak}

U radu se govori o posebnom aspektu papinsko-ugarskih odnosa, djelovanju delegirane jurisdikcije nakon mongolske invazije 1241-42, pri čemu je naglasak na oživljavanju sustava 40 -ih godina 13. stoljeća i na određenim mjerama pape Inocenta IV. iz 1252. i 1254. godine. Prvom mjerom ove vrste tradicionalno se smatra papina povlastica dodijeljena kralju Beli IV. kako bi se spriječilo da se njegovim crkvenim i laičkim podanicima sudi izvan kraljevstva. Ta je odluka, prema mišljenju mađarskog pravnog povjesničara Györgya Bónisa, poništena već 1259. godine. U ovoj studiji želimo pokazati kako se utjecaj povelja Inocenta IV. i Aleksandra IV. ne smije precijeniti iako su svakako bile od velike važnosti. Broj poznatih slučajeva koje su nadzirali papini suci značajno je opao 50-ih godina 13. stoljeća. Međutim, to se ne može se objasniti samo spomenutom papinskom poveljom, nego valja uzeti u obzir i druge čimbenike. Ključne riječi: papa Inocent IV., 13. stoljeće, papinsko-ugarski odnosi, Bela IV.

Gábor Barabás, Odjel za srednjovjekovnu i ranomodenu povijest, Sveučilište u Pečuhu, Rókus u. 2., H-7624 Pécs, Republika Mađarska, E-mail adresa: barabas.gabor@pte.hu; barab.gabor@gmail.com. 